УДК 343.137

DOI https://doi.org/10.32849/2663-5313/2020.8.46

Олександр Рибалка,

канд. юрид. наук, дочент,

адвокат

Ради адвокатів Черкаської області

\title{
ТЕОРЕТИЧНІ ЗАСАДИ ДОКАЗУВАННЯ В КРИМІНАЛЬНОМУ ПРОЦЕСІ
}

У статті проаналізовано питання щодо поняття і структури доказування, концептуальних проблем, пов'язаних із доказуванням у кримінальному процесі.

3'ясовано, що доказування як процедура отримання доказів $i$ їх застосування, що має на меті відтворення картини події, яка досліджуться, є засобом здобутку иілей кримінального судочинства, що має на меті захист прав $і$ законних інтересів учасників кримінального судочинства, розкриття злочинів і недопустимість покарання невинуватих. Вирішення судом правових конфліктів за межами доказової діяльності унеможливлює реалізацію судової влади. Отже, на думку більшості науковців, інститут доказів і доказування був і залишатиметься однією із засад кримінального процесу.

Також з'ясовано, що об'єктивних причин для зміни сформованого в теорії кримінального прочесу поняття, за яким доказування - ие і є пізнання обставин справи, що визначається в особливій процесуальній формі, немає. Доказування означає пізнавальну діяльність уповноважених суб'єктів iє специфічним юридичним, процесуальним терміном.

Доказування в кримінальному процесі є специфічним видом кримінально-процесуального пізнання, може визначатися як діяльність прокурора, слідчого, начальника слідчого відділу, органу дізнання, особи, яка провадить дізнання, основою якої є практичні дії та логічно-аналітичні операції, що проводяться з метою збирання, перевірки й оиінювання доказів для відповідного обгрунтування та мотивування процесуальних рішень з метою визначення істини в кримінальному провадженні та вирішення завдань кримінального судочинства.

У кримінально-процесуальному доказуванні різною мірою беруть участь усі суб'єкти правових відносин, що при ивому відбуваються. Можна також визначити, що повною мірою на всіх етапах доказування його суб'єктами є лише відповідні державні органи та посадові особи, а також ті учасники прочесу, участь яких зумовлена власним інтересом у справі, а також сторона захисту (представники сторін). Саме у зв'язку з діяльністю иих суб'єктів утворюється зміст прочесу кримінально-прочесуального доказування.

Ключові слова: доказування, докази, кримінальне судочинство, суб’єкти доказування, збирання доказів, оцінка доказів, перевірка доказів.

Постановка проблеми. Сдиним засобом досягнення цілей кримінального судочинства є доказування, що трактується як процес одержання доказів, їх використання, що має на меті відтворення дійсної картини події, яка досліджується, захист прав і законних інтересів осіб, які беруть участь у кримінальному судочинстві, розкриття злочинів, недопустимість покарання невинуватих. 3'ясування та вирішення судом правових суперечок за межами доказової діяльності, тобто реалізація судової влади, неможливі. У зв'язку з цим питання доказів і доказування, на думку більшості науковців, є й залишаються основою кримінального процесу.

Пізнання є невід'ємною філософською основою поняття доказування.

Із цією обставиною пов'язані теоретичні суперечки щодо співвідношення цих понять, змісту і структури доказування, кола суб'єктів та обов'язку доказування, особливостей його реалізації на різних стадіях процесу тощо.

Свогочасудорозглядуйнауковогоаналізу проблем доказування зверталися такі учені, як С. Альперт, Ю. Аленін, В. Бахін, А. Бєлкін, Т. Варфоломєєва, Г. Горський, Ю. Грошевий, М. Гошовський, А. Дубинський, А. Іщенко, Ц. Каз, О. Капліна, Н. Карпов, Л. Кокорєв, Ф. Кудін, О. Ларін, Є. Лук'янчиков, В. Маляренко, М. Михеєнко, В. Нор, Н. Обрізан, I. Петрухін, М. Погорецький, В. Попелюшко, В. Савицький, С. Стахівський, Ю. Стецовський, Л. Удалова, С. Шейфер, В. Шепітько, М. Шумило та ін. Фундаментальною основою для досягнення цілей, що стоять перед сторонами кримінального процесу, є доказування, саме завдяки процесу доказування сторони повністю реалізовують у кримінальному процесі свої законні інтереси, а сторо- 
ною обвинувачення повною мірою виконуються завдання щодо швидкого й повного розкриття злочину, викриття винних.

Метою статті є дослідження теоретичних основ поняття і структури доказування, концептуальних проблем, пов'язаних із доказуванням у кримінальному процесі.

Виклад основного матеріалу. У теорії доказів протягом тривалого часу закріплено уявлення про доказування як різновид пізнання обставин злочину, які мають значення для розслідування злочину та провадження в кримінальній справі, що характеризується єдністю двох взаємопов'язаних ступенів пізнання чуттєвого (безпосереднього) й раціонального (опосередкованого) [1, с. 280-287]. Ці закономірності не заперечують наявності суттєвих особливостей кримінально-процесуального доказування, що дає можливість погодитися з тими авторами, які підкреслюють, що процедура кримінально-процесуального доказування $є$ специфічною процесуальною методологією пізнання уповноваженими законом суб'єктами відповідного об'єкта дослідження [2, с. 4-6].

Так, на думку С. Алексєєва, доказування (у широкому значенні) - це діяльність суб'єктів, що спрямована на встановлення за допомогою доказів істинності обставин справи. Сюди автором включені збирання, перевірка й оцінювання доказів. У вузькому ж розумінні автор розглядає доказування як обгрунтування сформульованих доводів і заперечень, переконання в їхній істинності тих чи інших осіб [3, с. 247-248].

Обов'язок доказування, що покладається на визначених суб'єктів доказування, прийнято трактувати у двох значеннях - як обов’язок збирати, перевіряти й оцінювати докази з метою встановлення істини, а також як обов'язок обгрунтовувати свої висновки за допомогою доказів.

У літературі з кримінального процесу поняття доказування тлумачиться неоднозначно, незважаючи на вирішальну роль у встановленні обставин злочину. Велика кількість наукових досліджень цієї проблеми за різних часів лише ще більше підкреслює їі постійну актуальність. Передусім недостатньо дослідженим, очевидно, можемо визнати власне поняття «доказування».

Здебільшого кримінально-процесуальне доказування розглядають як практичну діяльність уповноважених законом суб'єктів, яка відбувається в особливій процесуальній формі шляхом збирання, перевірки й оцінювання доказів [4, с. 14].

Деякими процесуалістами розглядається процесуальне закріплення доказів як самостійний елемент процесу доказування. Відомий український процесуаліст М. Гродзинський, наприклад, уважав, що доказування - це діяльність слідчо-судових і прокурорських органів зі збирання, закріплення й оцінювання доказів [5, с. 117].

Можемо відзначити, що процесуальне закріплення фактичних даних не вважається самостійним елементом доказування, тому що воно є складником будь-якої слідчої дії, що проводиться з метою збирання чи перевірки доказів. Збирання доказів у процесуальних джерелах прийнято розглядати як врегульовану Кримінального процесуального кодексу (далі - КПК) України діяльність уповноважених суб'єктів з виявлення й фіксації в процесуальних документах і додатках до них матеріальних та ідеальних слідів злочину або іншої доказової інформації.

У світі не існує готових доказів, тому слідчий під час провадження слідчих дій, виявляючи належну до справи інформацію (сліди злочину) і фіксуючи їі в процесуальних актах, зайнятий формуванням доказів і їх процесуальних джерел.

Так, ще I. Бентам указував, що в доказі $€$ щось оманливе; видається, що нібито предмет, який так називається, має достатню силу, щоб йому довіряли; але під цим словом треба розуміти тільки засіб, котрий використовується для встановлення істинності факту, засіб, який може виявитися й поганим, і гарним, і повним, і недостатнім [6, с. 204].

Уважаємо за необхідне підкреслити, що передумови подальшої повної, усебічної, об'єктивної перевірки доказів створюються вже в процесі їх збирання, як і під час перевірки необхідні умови для розвитку подальшого процесу пізнання обставин злочину та забезпечення можливості оцінювання сукупності доказів у кримінальній справі. Процес перевірки доказів умовно можна розділити на практичні (слідчі) дії з пошуку нових доказів, а також логічні операції (аналіз і синтез) з дослідження зібраних доказів. Відповідно до ч. 1 ст. 94 КПК України, слідчий, прокурор, слідчий суддя, суд за своїм внутрішнім переконанням, яке грунтується на всебічному, повному й неупередженому дослідженні всіх обставин кримінального провадження, керуючись законом, оцінюють кожний доказ з погляду належності, допустимості, достовірності, а сукупність зібраних доказів - 3 погляду достатності й взаємозв'язку для прийняття відповідного процесуального рішення.

Вищевказане дає можливість охарактеризувати збирання й перевірку доказів як певні етапи формування фактичної основи процесу доказування. Це застосовується під 
час формування процесуальних актів, де встановлюються обставини за допомогою логічного використання доказів, що мають значення для кримінального провадження, а також обгрунтування й мотивування процесуальних рішень, що є наслідком установлених і досліджених обставин.

Практична діяльність зі збирання та перевірки доказів і процесуальне доказування, а також відмінність між ними здавна досліджуються фахівцями. Юристи ХIX ст.: I. Бентам, Л. Володимиров, I. Фойницький, М. Розін та інші - під доказуванням розуміють саме логічні операції з використання доказів в обгрунтуванні процесуальних рішень перед судом, хоча при цьому підкреслюють важливу роль процесуального збирання й перевірки доказів як «одної з гарантій судової достовірності».

Так, Л. Володимиров уважав, що доказом є будь-який факт, який має призначення викликати в судді переконання в існуванні або неіснуванні будь-якої обставини, що становить предмет судового дослідження. Кримінальний доказ отримує значення судового, коли він має юридичні ознаки, які вимагаються законом. Такі ознаки даються встановленими способами збирання й використання доказів [7, с. 133-134]. Отже, поняття доказу (доказування) принципово визначається не його пошуковою спрямованістю, а його призначенням - бути знаряддям обгрунтування встановленого.

На думку В. Арсеньєва, Я. Мотовиловкера, М. Михеєнка та інших, доказування має два різновиди: а) «процесуальне доказування», або доказування як дослідження фактичних обставин, тобто діяльність відповідних органів та осіб зі збирання, перевірки й оцінювання доказів; б) «логічне доказування», тобто логічне та процесуальне обгрунтування певної тези, твердження, висновків у справі.

Так, В. Савицький визначає сутність доказування виключно як обгрунтування певного твердження, тези, водночас уважаючи, що необхідно рахуватися також із традиційним ототожненням у юриспруденції доказування та практичної діяльності 3 формування й перевірки доказів, а також із тим, що в кримінальному процесі термін «доказування» вживається в обох значеннях [8, с. 149-153].

Отже, якщо в процесі формування й перевірки доказів метою є створення властивих засобів (доказів), то в процесі доказування обставин злочину ці засоби мають застосовуватися шляхом аргументації, обгрунтування ними певних тез (висновків, процесуальних рішень). Відбувається це під час доказування, у відмінних процесуальних формах (у постановах, обвинувальних актах, ухвалах, вироках суду) і лише за допомогою раціонального (опосередкованого) пізнання, через аналіз достатності сукупності доказів для прийняття процесуальних рішень та обгрунтування певних тез.

Під час збирання доказів і встановлення результатів слідчих дій слідчий (особа, яка провадить дізнання) здійснює пізнання для всієї системи суб'єктів, у якій є й сторона обвинувачення, і сторона захисту, і суд. Щодо переконання їх у правильності своїх висновків слідчим і проводяться вищевказані дії, що мають спрямування на переформатування «істини в собі» на «істину для всіх».

Отже, обгрунтування правильності висновків, тобто доказування в логічному (вузькому) аспекті, лише завершується складанням підсумкового процесуального акта (повідомлення про підозру, обвинувальний акт), воно бере свій початок і триває під час отримання знань, тобто в процесі збирання й перевірки доказів.

Оскільки процес доказування не обмежується лише логічними операціями з обгрунтування висновків, а містить у собі пізнавальну діяльність, що пов'язана з отриманням фактів для обгрунтування, тобто доказів, важливим є з'ясування того, як саме в кримінальному провадженні з'являються ці факти, тобто докази.

На думку С. Шейфера, формування доказів передусім має зміст у перетворенні первинної доказової інформації, тобто інформації, що вилучається суб'єктом доказування зі слідів, залишених подією [9, с. 33]. Тому можна стверджувати, що збирання, точніше, формування доказів - це комплекс операцій, що здійснюється суб'єктом доказування, що полягають у виявленні носіїв інформації, іï сприйнятті й перетворенні в належну процесуальну форму (форму показань, висновків експерта тощо).

Фінальним елементом формування доказів є їх фіксація. Саме із цього моменту відбувається об'єктивізація сприйнятих суб'єктом доказування даних, вони закріплюються за допомогою передбачених законом засобів фіксації.

На думку М. Строговича, поки доказ не розглянутий і не закріплений процесуально, не можна стверджувати, що доказ дійсно виявлений, оскільки ще не відомо, що саме виявлено та чи дійсно є доказом те, що виявлено [10, с. 302].

Отже, доказування в кримінальному судочинстві - це врегульований нормами кримінально-процесуального права процес набуття істинних знань про подію та обставини злочину. 


\section{Висновки}

Причин для перегляду сформованого в теорії кримінального процесу поняття, відповідно до якого доказування - це іє пізнання обставин справи, що проявляється в особливій процесуальній формі, немає. Доказування $\epsilon$ специфічним юридичним, процесуальним терміном, що означає пізнавальну діяльність уповноважених суб'єктів. Саме завдяки такому визначенню кримінально-процесуального доказування відбувається запобігання як виключення з доказування практичних операцій з формування доказів (а отже, i їx недооцінка), так й ігнорування правил логіки доказування й зумовлені цим спроби визначити достатність доказів на рівні інтуїції, усвідомленні посадовою особою.

\section{Список використаних джерел:}

1. Теория доказательств в советском уголовном процессе / под ред. Н.В. Жогина. 2-е изд., доп. Москва : Юрид. лит., 1973. 735 с.
2. Шейфер С.А. Следственные действия Система и процессуальная форма. Москва, 1981. $128 \mathrm{c}$

3. Алексеев С.С. Проблемы теории права. Свердловск, 1973. Т. 2. 401 с

4. Стахівський С.М. Теорія і практика кримінально-процесуального доказування : монографія. Київ, 2005. 272 с.

5. Гродзинский М.М. Улики в советском уголовном процессе. Москва : Госюриздат, 1945. $227 \mathrm{c}$

6. Бентам И. О судебныхъ доказательствахъ. Киев, 1876. 421 с.

7. Владимиров Л.Е. Учение об уголовных доказательствах. Тула, 2000. 464 с.

8. Савицкий В.М. Язык процессуального закона (вопросы терминологии). Москва, 1987. 286 c.

9. Шейфер С.А. Доказательства и доказывание по уголовным делам: проблемы теории и правового регулирования : монография Москва : Норма, 2009. 239 с.

10. Строгович М.С. Курс советского уголовного процесса. Москва, 1971. Т. 1.470 с.

Oleksandr Ribalka. Theoretical ambush of proof in criminal process

The article analyzes the concept and structure of evidence, conceptual problems associated with evidence in criminal proceedings.

It was found that evidence, as a procedure for obtaining evidence and their application, aimed at reproducing the picture of the event under investigation, is a means of achieving the objectives of criminal proceedings, aimed at protecting the rights and legitimate interests of criminal proceedings, crime detection and inadmissibility of punishment innocent. The resolution of legal conflicts by the court outside the evidentiary activity makes it impossible to exercise judicial power. Thus, according to the vast majority of scholars, the institution of evidence and proof was and will remain one of the foundations of the criminal process.

It was also found that there are no objective reasons for changing the concept formed in the theory of criminal procedure, according to which proof is the knowledge of the circumstances of the case, which is determined in a special procedural form. Evidence means the cognitive activity of authorized subjects and is a specific legal, procedural term.

Evidence in criminal proceedings is a specific type of criminal procedural knowledge, and can be defined as the activities of the prosecutor, investigator, head of the investigative department, body of inquiry, person conducting the inquiry, based on practical actions and logical-analytical operations conducted for collection, verification and evaluation of evidence for appropriate substantiation and motivation of procedural decisions in order to determine the truth in criminal proceedings and solve the problems of criminal proceedings.

All subjects of legal relations that take part in criminal procedural evidence take part in different degrees. It can also be determined that at all stages of proving its subjects are only the relevant government agencies and officials, as well as those participants in the process, whose participation is due to their own interest in the case, as well as the defense (representatives of the parties). It is in connection with the activities of these subjects that the content of the process of criminal procedural evidence is formed.

Key words: evidence, proving, criminal proceedings, subjects of evidence, collection of evidence, evaluation of evidence, verification of evidence. 